\title{
Prenatal Diagnosis of Fetal Cataract: Case Report and Review of the Literature
}

\author{
Alexandre Léonard Pierre Bernard Anne-Lise Hiel Corinne Hubinont \\ Department of Obstetrics, Saint Luc University Hospital, Université Catholique de Louvain, Brussels, Belgium
}

\section{Key Words}

Fetal $\cdot$ Ultrasound $\cdot$ Eye $\cdot$ Lens $\cdot$ Cataract $\cdot$ Congenital abnormalities $\cdot$ Aneuploidy

\begin{abstract}
Objectives: To report a case of prenatally diagnosed fetal cataract and conduct a systematic review of previously reported cases. Methods: Review of the literature based mainly on Pubmed search using specific keywords in order to list cataract causes diagnosed prenatally and in early childhood, isolated or associated with microphthalmia. Results and Discussion: A differential diagnosis list and specific prenatal diagnosis testing are suggested in order to offer the best management of this rare fetal condition.
\end{abstract}

Copyright $\odot 2009$ S. Karger AG, Basel

\section{Background}

Cataract is defined by the presence of any lens opacity. The incidence of congenital cataract ranges from 1 to 6 newborn infants out of 10,000 births [1].

Cataract development is strongly linked to the embryonic ocular development. The lens differentiates from the surface ectoderm before the sixth week of gestation, explaining the absence of cataract in case of late first-trimester fetal infection $[2,3]$.

A large number of genes causing congenital cataract have been mapped or cloned, but most of them are not yet used in clinical practice. Several ocular development genes may be affected, thereby inducing a lens proteins synthesis default such as the major intrinsic protein, which plays a role in the cortical and nuclear formation of the lens [4-6]. A genetic cause is responsible for $30 \%$ of unilateral cataracts and $50 \%$ of bilateral cataracts. The transmission mode may be autosomal dominant, recessive, or X-linked. A neomutation is found in $25 \%$ of cases. In general, autosomal dominant transmission is associated with symmetrical and bilateral cataracts without systemic anomalies. A similar prevalence is observed in both sexes for unilateral and bilateral forms [7-9].

When a fetal cataract is observed, an early treatment should be started immediately after birth in order to prevent severe amblyopia or glaucoma.

\section{Objectives}

The improvement of ultrasound imaging allows the diagnosis of fetal ocular anomalies that could be easily missed in the postnatal period. Fetal ultrasound of the orbital region should also be offered when there is a family history of congenital ocular anomaly [10]. When a fetal cataract is observed, it is important to list the differential diagnosis possibilities and to offer the specific prenatal testing.

The following case report of fetal cataract associated with microphthalmia confirms the difficulty for prenatal diagnosis and management.

\section{KARGER}

Fax +4161306 1234 E-Mail karger@karger.ch www.karger.com

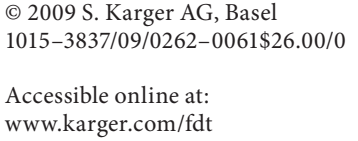

Prof. C. Hubinont

Department of Obstetrics, Saint Luc University Hospital

10 avenue Hippocrate

BE-1200 Brussels (Belgium)

Tel. +32 2764 1014, Fax +32 2764 8913, E-Mail corinne.hubinont@uclouvain.be 


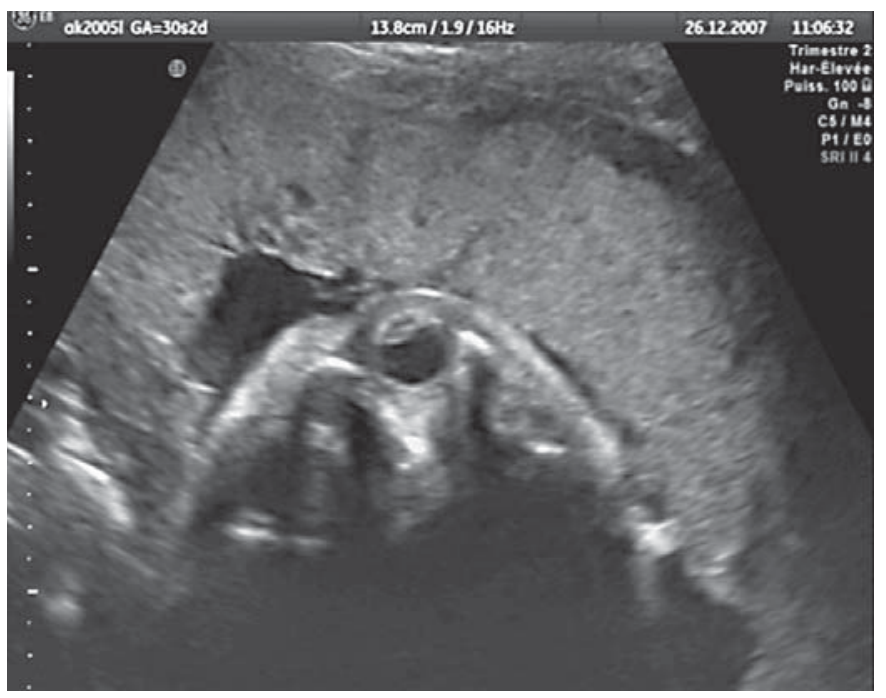

Fig. 1. Ultrasound cataract diagnosis at 30 weeks of gestation.

As differential diagnosis references were difficult to find, the aim of this paper is to report both diagnostic and therapy management algorithms for this severe fetal condition.

\section{Data Sources}

For the literature review, we searched the Pubmed database, without any restriction of publication date or journal, with recognized experts and cross-referencing relevant material.

Most causes of cataract in early childhood were identified using the following key words, which were combined using all possibilities: fetal, prenatal and congenital in association with cataract, lens, eye, ocular, orbit, small eye and microphthalmia, ultrasound. Among them, we checked those diagnosed prenatally. For each cause, a new search was done through Pubmed to complete the table data.

\section{Results}

\section{Case Report}

A 26-year-old pregnant woman was referred because the fetal lenses were not properly visualized during the morphological second trimester scan. At 27 2/7 weeks'

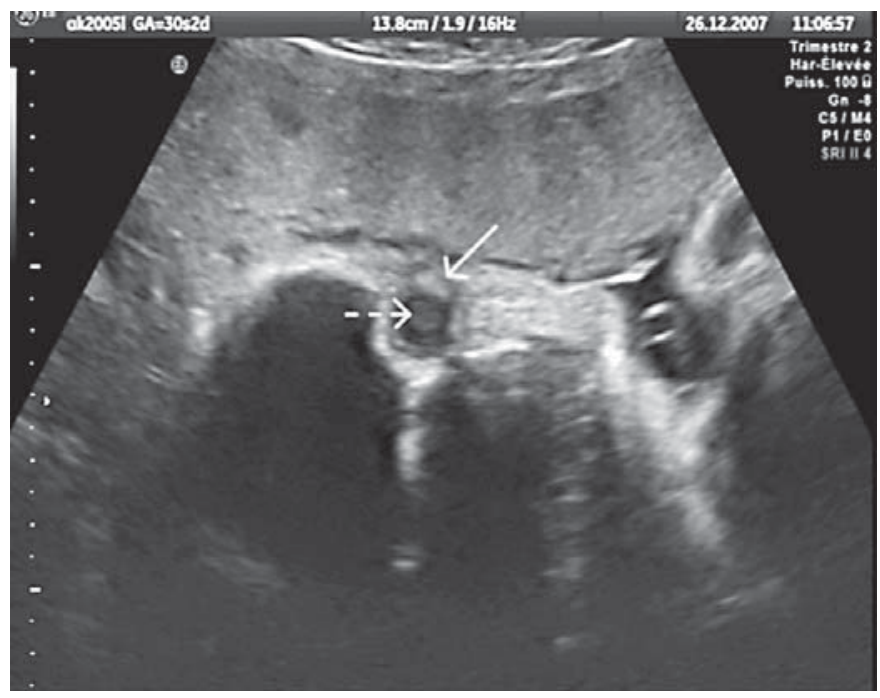

Fig. 2. Ultrasound of orbital region at 30 weeks of gestation with highly echogenic lens (full arrow); behind the lens, the primitive vitreous is visible (dashed arrow).

gestation, fetal ultrasound was normal, except for 2 highly echogenic lenses. Lens diameter was $5.8 \mathrm{~mm}$, normal according to the literature [11-13].

Subsequent ultrasound assessment confirmed similar findings (fig. 1,2). The patient's medical and family history was uneventful. No other fetal anomalies were evidenced. Then, no complementary invasive investigations were performed.

The pregnancy outcome was normal. The child was born vaginally at term with a birth weight of $2.995 \mathrm{~kg}$ and a length of $46.5 \mathrm{~cm}$. Postnatal clinical examination revealed the presence of bilateral lower limbs clinodactyly (toes 4 and 5), low implantation of the ears, micropenis associated with a small right testicle. Development retardation and major axial hypotonia were also observed, with permanently clenched fists and positive Babinski's sign. Postnatal ophthalmological examination showed the additional presence of microphthalmia, not observed antenatally, with an ocular globe axis of $12 \mathrm{~mm}$ (5th centile: $16 \mathrm{~mm}$; 95th centile: $21 \mathrm{~mm}$ ) [14].

The combination of microphthalmia with fetal cataract, hypogenitalism and hypotonia suggested a final diagnosis of Micro syndrome [15].

This case report is interesting for several reasons. It confirms the difficulty for detecting microphthalmia prenatally and we could not find references about the differential diagnosis of fetal cataract associated with or without microphthalmia. 
Table 1. Causes of fetal cataract already observed on prenatal ultrasonography

\begin{tabular}{|c|c|c|c|c|}
\hline Syndrome & Frequency & Genetics and etiology & $\begin{array}{l}\text { Principal ultrasonographic findings, in addition to } \\
\text { cataract }\end{array}$ & Diagnosis \\
\hline \multicolumn{5}{|l|}{ Facio-craniostenoses } \\
\hline $\begin{array}{l}\text { Apert syndrome } \\
{[22-24]}\end{array}$ & $1 / 160,000$ & $\begin{array}{l}\text { AD; chrom. 10; } \\
\text { FGFR2 gene }\end{array}$ & $\begin{array}{l}\text { Acrosyndactyly with mitten hands and syndactyly of } \\
\text { the feet; turribrachycephaly; clover leaf skull }\end{array}$ & US; causal mutation \\
\hline \multicolumn{5}{|c|}{ Polymalformation and complex cranio-facial malformation syndromes } \\
\hline $\begin{array}{l}\text { Smith-Lemli-Opitz } \\
\text { syndrome }[25,26]\end{array}$ & $\begin{array}{l}1 / 20,000- \\
1 / 30,000\end{array}$ & $\begin{array}{l}\text { AR; chrom. } 11 ; \\
\text { DHCR7 gene }\end{array}$ & $\begin{array}{l}\text { Microretrognathism; nasal anteversion; wide } \\
\text { forehead; atrioventricular septum defect; renal } \\
\text { hypoplasia; postaxial hexadactyly; IUGR affecting } \\
\text { mainly the long bones; micropenis }\end{array}$ & $\begin{array}{l}\text { US; maternal plasma with } \\
\text { oestriol } \downarrow \text {; normal caryotype; } \\
\text { from } 13 \mathrm{~W} \text {, AFP with 7- } \\
\text { DHC } \uparrow \text { and cholesterol } \downarrow\end{array}$ \\
\hline $\begin{array}{l}\text { Hallerman Streiff } \\
\text { syndrome [27-29] }\end{array}$ & Rare & $\begin{array}{l}\text { Sporadic; etiology } \\
\text { unknown }\end{array}$ & $\begin{array}{l}\text { Microcephaly; frontal bossing; micrognathia; bird } \\
\text { head; beaky nose; teeth at birth; microphthalmia; } \\
\text { small proportional stature }\end{array}$ & US \\
\hline $\begin{array}{l}\text { Rubinstein Taybi } \\
\text { syndrome }[30,31]\end{array}$ & $1 / 125,000$ & $\begin{array}{l}\text { AD/neomutation; } \\
\text { CBP gene (chrom. 16) or } \\
\text { EP300 (chrom. 22) }\end{array}$ & $\begin{array}{l}\text { Large thumbs; large toes; small stature; } \\
\text { antimongoloid palpebral fissures }\end{array}$ & $\begin{array}{l}\text { US, difficult since not very } \\
\text { specific }\end{array}$ \\
\hline
\end{tabular}

\begin{tabular}{|c|c|c|c|c|}
\hline \multicolumn{5}{|c|}{ Musculoskeletal conditions } \\
\hline $\begin{array}{l}\text { Chondrodysplasia } \\
\text { punctata syndrome } \\
{[32,33]}\end{array}$ & $1 / 100,000$ & $\begin{array}{l}\text { AR; PEX gene for peroxin } 7 \text {; } \\
\text { peroxysomal transfer } \downarrow\end{array}$ & $\begin{array}{l}\text { Short femurs and humerus; proximal epiphyseal } \\
\text { punctuations; congenital, early, bilateral, total } \\
\text { cataract in almost } 50 \% \text { of the cases }\end{array}$ & US \\
\hline $\begin{array}{l}\text { Walker-Warburg } \\
\text { syndrome [34-36] }\end{array}$ & $1.2 / 100,000$ & $\begin{array}{l}\text { AR; POMT1, POMT2, } \\
\text { FKRP gene }\end{array}$ & $\begin{array}{l}\text { Dandy-Walker malformation; hydrocephaly; } \\
\text { lissencephaly; microcephaly; microphthalmia; retinal } \\
\text { detachment }\end{array}$ & $\begin{array}{l}\text { US; in utero muscle biopsy; } \\
\text { genetic }\end{array}$ \\
\hline $\begin{array}{l}\text { Roberts syndrome } \\
{[37,38]}\end{array}$ & Very rare & $\begin{array}{l}\text { AR probable; etiology } \\
\text { unknown }\end{array}$ & $\begin{array}{l}\text { Reductional anomalies of the limbs similar to } \\
\text { phocomelia; round face; hypertelorism; } \\
\text { microretrognathia; labiopalatine fissure }\end{array}$ & $\begin{array}{l}\text { US; AC: premature } \\
\text { centromere separation }\end{array}$ \\
\hline
\end{tabular}

\section{Aneuploidism and chromosomal anomalies}

Trisomy 13 [39] 1/10,000

Holoprosencephaly; Fallot tetralogy; septal defect (VSD, ASD); omphalocele; hydronephrosis; club foot;

US; fetal caryotype cystic kidney; microphthalmia

\begin{tabular}{lll}
\hline Trisomy $18[40]$ & $1 / 8,000$ & $\begin{array}{l}\text { Low ears; micrognathia; microphthalmia; } \\
\text { omphalocele; septal defect (VSD, ASD); IUGR; } \\
\text { overlapping fingers }\end{array}$ \\
\hline Trisomy $21[41,42] \quad 1 / 700$ & $\begin{array}{l}\text { Nuchal translucency; mongoloid palpebral fissures; } \\
\text { defect of nasal bones; cardiac (Fallot tetralogy), } \\
\text { gastroduodenal (duodenal atresia), urinary } \\
\text { (pyelectasis) anomalies; } 40 \% \text { has cataracts, but not } \\
\text { necessarily in the antenatal period }\end{array}$ \\
\hline
\end{tabular}

Others $[9,41] \quad$ Triploidism, monosomy, deletion (5p), duplication

US; fetal caryotype

\begin{tabular}{lll}
\hline \multicolumn{2}{l}{ Cutaneo-dental disorders } & \\
Nance Horan & Rare & Semi-dominant; \\
syndrome $[43,44]$ & & chrom. X
\end{tabular}

syndrome $[43,44] \quad$ chrom. X
In $100 \%$ of cases: male sex and congenital bilateral dense, most often total cataract. Also possible: microcornea ( $<10 \mathrm{~mm}$ in diameter); microphthalmia; long face; prognathism; large nose; large protruding ears; dental anomalies
US difficult; to our knowledge, only one publication exists on prenatal diagnosis of Nance-Horan syndrome

US laborious; plasma and amniocytes: LCFA, with $(\mathrm{C} 26: 1) \uparrow$ and $(\mathrm{C} 26: 0) \uparrow$

$\begin{array}{lll}\begin{array}{l}\text { Metabolic disorders } \\ \text { Zellweger syndrome } \\ \text { [45-47] }\end{array} \quad \text { AR } & & \\ & & \begin{array}{l}\text { Prominent forehead; hypertelorism; mongoloid } \\ \text { palpebral fissures; depressed nasal root; }\end{array} \\ & \begin{array}{l}\text { retrognathism; micrognathism; subcortical renal } \\ \text { cysts; cardia defect; small stature; nuchal }\end{array} \\ & \text { translucency; absent corpus callosum; abnormal } \\ \text { neuronal migration (MRI) }\end{array}$

Prominent forehead; hypertelorism; mongoloid palpebral fissures; depressed nasal root; cysts; cardia defect; small stature; nucha neuronal migration (MRI) 
Table 1 (continued)

\begin{tabular}{|c|c|c|c|c|}
\hline Syndrome & Frequency & Genetics and etiology & $\begin{array}{l}\text { Principal ultrasonographic findings, in addition to } \\
\text { cataract }\end{array}$ & Diagnosis \\
\hline $\begin{array}{l}\text { Lowe's Oculo- } \\
\text { cerebro-renal } \\
\text { syndrome }[48-50]\end{array}$ & $1 / 500,000$ & $\begin{array}{l}\text { X-linked; recessive; } \\
\text { OCRL1 protein gene, coding } \\
\text { for Ptdlns }(4,5) \mathrm{P} 2\end{array}$ & $\begin{array}{l}\text { Early congenital cataract in all patients affected; } \\
\text { antenatal diagnosis of cataract is possible and has } \\
\text { already been reported }\end{array}$ & $\begin{array}{l}\text { US not very conspicuous; } \\
\text { AFP: AC with } \\
\text { Ptdlns }(4,5) \text { P } 2 \downarrow \text { and } \\
\text { abnormal PCR mRNA of } \\
\text { OCRL1 }\end{array}$ \\
\hline $\begin{array}{l}\text { Infectious diseases } \\
\text { Rubella }[3,51,52]\end{array}$ & $\begin{array}{l}\text { First cause } \\
\text { of congenital } \\
\text { cataract }\end{array}$ & $\begin{array}{l}\text { After the } 6 \text { th } W \text {, the lens } \\
\text { vesicle is separated, limiting } \\
\text { viral access }\end{array}$ & $\begin{array}{l}\text { Cardiac malformations (septal defects, pulmonary } \\
\text { artery hypoplasia); microphthalmia; microcephaly; } \\
\text { polycystic kidneys; IUGR; splenomegaly; } \\
\text { hepatomegaly }\end{array}$ & $\begin{array}{l}\text { US; serology; AFP } \\
\text { (culture, PCR) }\end{array}$ \\
\hline Varicella $[9,51]$ & & & $\begin{array}{l}\text { Limb hypoplasia; microphthalmia; positional } \\
\text { anomalies of the extremities; intracranial } \\
\text { calcifications; polyhydramnios; hydrocephaly; highly } \\
\text { echogenic liver }\end{array}$ & $\begin{array}{l}\text { US; serology; AFP } \\
\text { (culture, PCR) }\end{array}$ \\
\hline CMV $[51,53]$ & $\begin{array}{l}2.3 / 100- \\
4 / 100\end{array}$ & & $\begin{array}{l}\text { Hepatosplenomegaly; microcephaly; IUGR; cerebral/ } \\
\text { hepatic calcifications; highly echogenic intestine; } \\
\text { ventriculomegaly }\end{array}$ & $\begin{array}{l}\text { US; serology; AFP } \\
\text { (culture, PCR) }\end{array}$ \\
\hline Herpes simplex $[9,51]$ & & & $\begin{array}{l}\text { Microcephaly; microphthalmia; hydranencephaly; } \\
\text { multicystic encephalomalacia; ascites; intrahepatic } \\
\text { calcifications }\end{array}$ & $\begin{array}{l}\text { US; serology; AFP } \\
\text { (culture, PCR) }\end{array}$ \\
\hline
\end{tabular}

Toxins

Corticosteroids, antipsychotic drugs such as chlorpromazine [54, 55]: harmful effects on lens but no publications of fetal cataract.

Coumarin derivatives $[56,57]$ : punctuated chondrodysplasia, nasal hypoplasia, brachytelephalangic, microphthalmia, reports of cataract.

Idiopathic

Most fetal cataracts are idiopathic, but no accurate data are available on the percentage.

$\mathrm{AD}=$ Autosomal dominant; $\mathrm{AR}=$ autosomal recessive; chrom. = chromosome; $\mathrm{US}=$ ultrasound; $\mathrm{AFP}=$ amniotic fluid puncture; $\mathrm{AC}=$ amniocyte culture; 7-DHC = 7-dehydrocholesterol; AFP = $\alpha$-fetoprotein; IUGR = intauterine growth retardation; LCFA = long chain fatty acids.

\section{Systematic Review of Cataract Already Observed on}

Prenatal Ultrasonography

Table 1 reports congenital cataract causes occurring in the fetus. It is important to notice that some disorders have never been reported prenatally and are therefore not included in the differential diagnosis, such as Steinert myotonic dystrophy, Turner syndrome [16, 17], Alport syndrome [18], Stickler syndrome and glucose-6-phosphatase dehydrogenase deficiency $[19,20]$. Cataract due to in utero fetal irradiation may occur after some delay and then may not be identified during fetal life. Finally, only a single case of fetal cataract secondary to toxoplasma infection has been reported and we did not include it in the table [21].

Some disorders reported in table 1 can be associated with both fetal microphthalmia and cataract: Hallerman-Streiff, Walker-Warburg and Nance Horan syndrome; trisomy 13 and 18; rubella, varicella, herpes simplex fetal infection; coumarin derivatives used during pregnancy. Other syndromes can present cataract and can be associated with microphthalmia, but up to now, these rare syndromes were confirmed only postnatally, such as Micro syndrome (mental retardation, microcephaly, hypogenitalism, hypotonia, atonic pupils, corpus callosum anomalies...) [15,58], Martsolf syndrome (mental retardation, small stature, hypogonadism, microcephaly...) [58-60], clinical signs in the spectrum of phenotypes that range from Micro syndrome to Martsolf syndrome [61], cerebro-oculo-facio-skeletal syndrome [62, 63], and some chromosomal anomalies such as $46, \mathrm{XX}, \operatorname{inv}(2)$ (p21q31) [64].

One case of antenatal severe bilateral microphthalmia associated with cerebro-ocular-facio-skeletal syndrome was reported antenatally on ultrasound findings, mainly micrognathia, multiple joint contractures and rockerbottom feet. But so far, no prenatal cataract has been described though this may be part of the clinical picture [65]. 
Table 2. Proposal of management and differential diagnosis in cataracts detected on fetal ultrasonography, in combination with antenatal or postnatal microphthalmia

\begin{tabular}{l|l}
\hline \\
Reduced fetal eye size \\
observed on fetal US
\end{tabular}

Table 2 summarizes a management proposal in case of US fetal cataract diagnosis in combination with microphthalmia. Microphthalmia could sometimes be missed on prenatal ultrasound, as in this case report. Microphthalmia can be associated with microspherophakia, defined by the presence of an abnormally small lens. According to our knowledge, isolated fetal microspherophakia has never been reported in the literature.

\section{Discussion}

This case report was the opportunity to review fetal cataract causes and to offer a management algorithm. The finding of associated ultrasound signs is important in order to focus on the final diagnosis, in this case, Micro syndrome. Prenatal orbital region ultrasound should be part of the level II fetal scan as it could detect fetal cataract and other ocular disorders, such as retinoblastoma $[66,67]$.

The prenatal diagnosis of ophthalmologic abnormalities ensures a postnatal follow-up. In case of unilateral cataract, treatment should be started as soon as possible as unilateral visual stimulation is dependant upon a more rapid discontinuation of the cellular neuronal development. Moreover, a break in the neuronal density curve is observed from the fourth week of life in the newborn [68]. In bilateral forms, this break occurs only after 8 weeks. In the severe forms, surgery is then imperative within the following weeks. The aim of this early intervention is to limit the risk of amblyopia. Treatment of cataracts in the newborn includes etiologic findings, surgical treatment, treatment of a mblyopia and long-term supervision. Longterm follow-up is essential, whether or not surgery is performed [9]. If the cataract is complicated by nystagmus, strabism or if amblyopia correction is not conclusive, visual prognosis is poor.

In conclusion, this case report and proposal of management algorithm should encourage ultrasonographers to perform an accurate examination of the eyes in order to detect ocular anomalies, such as cataract, microphthalmia or persistent hyperplastic primary vitreous [69]. 


\section{References}

1 Francis PJ, Berry V, Bhattacharya SS, Moore AT: The genetics of childhood cataract. J Med Genet 2000;37:481-488.

-2 Thut CJ, Rountree RB, Hwa M, Kingsley DM: A large-scale in situ screen provides molecular evidence for the induction of eye anterior segment structures by the developing lens. Dev Biol 2001;231:63-76.

-3 Karkinen-Jääskeläinen M, Saxen L, Vaheri A, Leinikki P: Rubella cataract in vitro: sensitive period of the developing human lens. J Exp Med 1975;141:1238-1248.

-4 Berry V, Francis P, Kaushal S, Moore A, Bhattacharya SS: Missense mutations in MIP underlie autosomal dominant polymorphic and lamellar cataract linked to 12q. Nature Genet 2000;25:15-17.

5 Jamieson R, Perveen R, Kerr B, Carette M, Yardley J, Heon E, Wirth G, van Heinigen V, Donnai D, Munier F, Black G: Domain disruption and mutation of the BZIP transcription factor, MAF, associated with cataract, ocular anterior segment dysgenesis and coloboma. Hum Mol Genet 2002;11:33-42.

-6 Percin E, Ploder LA, Yu JJ, Arici K, Horsford DJ, Rutherford A, Bapat B, Cox DW, Duncan AM, Kalnins VI, Kocak-Altintas A, Sowden JC, Trabousli E, Sarfarazi M, McInnes RR: Human microphthalmia associated with mutations in the retinal homeobox gene CHX10. Nat Genet 2000;25:397-401.

$\checkmark 7$ Rahi JS, Dezateux C: Congenital and infantile cataract in the United Kingdom: underlying or associated factors. Invest Ophthalmol Vis Sci 2000;41:2108-2114.

8 Scott MH, Hejtmancik JF, Wozencraft LA, Reuter LM, Parks MM, Kaiser-Kupfer MI: Autosomal dominant congenital cataract. Interocular phenotypic variability. Ophthalmology 1994;101:66-71.

$\checkmark 9$ Roche O, Beby F, Orssaud C, Monod SD, Dufier JL: Congenital cataract. J Fr Ophtalmol 2006;29:443-455.

10 Mashiach R, Vardimon D, Kaplan B, Shalev J, Meizner I: Early sonographic detection of recurrent fetal eye anomalies. Ultrasound Obstet Gynecol 2004;24:640-643.

-11 Dilmen G, Köktener A, Turhan NO, Tez S: Growth of the fetal lens and orbit. Int J Gynaecol Obstet 2002;76:267-271.

12 Achiron R, Gottlieb Z, Yaron Y, Gabbay M, Gabbay U, Lipitz S, Mashiach S: The development of the fetal eye: in utero ultrasonographic measurements of the vitreous and lens. Prenat Diagn 1995;15:155-160.

13 Sukonpan K, Phupong V: A biometric study of the fetal orbit and lens in normal pregnancies. J Clin Ultrasound 2008;00:000-000.

14 Romero R, Pilu G, Jeanty P, Ghidini A, Hobbins JC: Normal anatomy of the face: growth of the ocular parameters; in Delauter DL (ed): Prenatal Diagnosis of Congenital Anomalies. Norwalk, Appleton and Lange, 1988, pp 83-86.
15 Derbent M, Agras P, Gedik S, Oto S, Alehan F, Saatci U: Congenital cataract, microphthalmia, hypoplasia of corpus callosum and hypogenitalism: report and review of Micro syndrome. Am J Med Genet A 2004;128: 232-234.

16 Papp C, Beke A, Mezei G, Szigeti Z, Bán Z, Papp Z: Prenatal diagnosis of Turner syndrome, report on 69 cases. J Ultrasound Med 2006;25:711-717.

17 Beby F, Roche O, Burillon C, Denis P: Coats' disease and bilateral cataract in a child with Turner syndrome: a case report. Graefes Arch Clin Exp Ophthalmol 2005;243:12911293.

18 Heidet L, Dahan K, Zhou J, Xu Z, Cochat P, Gould JD, Leppig KA, Proesmans W, Guyot C, Guillot M, et al: Deletions of both $\alpha 5$ (IV) and $\alpha 6$ (IV) collagen genes in Alport syndrome and in Alport syndrome associated with smooth muscle tumours. Hum $\mathrm{Mol}$ Genet 1995;4:99-108.

19 Bakhshi S, Kabra M: Glucose-6-phosphate dehydrogenase deficiency with bilateral cataract. Indian Pediatr 2004;41:630-631.

-20 Orzalesi N, Sorcinelh R, Guiso G: Increased incidence of cataract in male subjects deficient in glucose-6-phosphate dehydrogenase. Arch Ophthalmol 1981;99:69-70.

-21 Pedreira DA, Diniz EM, Schultz R, Faro LB, Zugaib M: Fetal cataract in congenital toxoplasmosis. Ultrasound Obstet Gynecol 1999; 13:266-267.

22 Chenoweth-Mitchell C, Cohen GR: Prenatal sonographic findings of Apert syndrome. J Clin Ultrasound 1994;22:510-514.

23 Boog G, Le Vaillant C, Winer N, David A, Quere MP, Nomballais MF: Contribution of tridimensional sonography and magnetic resonance imaging to prenatal diagnosis of Apert syndrome at mid-trimester. Fetal Diagn Ther 1999;14:20-23.

24 Ferreira JC, Carter SM, Bernstein PS, Jabs EW, Glickstein JS, Marion RW, Baergen RN, Gross SJ: Second-trimester molecular prenatal diagnosis of sporadic Apert syndrome following suspicious ultrasound findings. Ultrasound Obstet Gynecol 1999;14:426430.

25 McGaughran J, Donnai D, Clayton P, Mills K: Diagnosis of Smith-Lemli-Opitz syndrome. N Engl J Med 1994;330:1685-1687.

26 Dubuisson J, Guibaud L, Combourieu D, Massardier J, Raudrant D: Utility of fetal ultrasonography in the prenatal diagnosis of Smith-Lemli-Opitz syndrome. Gynecol Obstet Fertil 2008;36:525-528.

27 Nicholson AD, Menon S: Hallerman-Streiff syndrome. J Postgrad Med 1995;41:22-23.

28 Ertekin V, Selimoglu MA, Selimoglu E: Nonlethal Hallermann-Streiff syndrome with bone fracture: report of a case. Ann Genet 2004;47:387-391.
29 Sigirci A, Alkan A, Bicak U, Yakinci C: Hallermann-Streiff syndrome associated with complete agenesis of the corpus callosum. J Child Neurol 2005;20:691-693.

30 Hennekam R: Rubinstein-Taybi syndrome. Eur J Hum Genet 2006;14:981-985.

31 Wiley S, Swayne S, Rubinstein JH, Lanphear NE, Stevens CA: Rubinstein-Taybi syndrome medical guidelines. Am J Med Genet A 2003; 119:101-110.

-32 Basbug M, Serin IS, Özçelik B, Günes T, Akçakus M, Tayyar M: Prenatal ultrasonographic diagnosis of rhizomelic chondrodysplasia punctata by detection of rhizomelic shortening and bilateral cataracts. Fetal Diagn Ther 2005;20:171-174.

33 Motley AM, Hettema EH, Hogenhout EM, Brites P, ten Asbroek AL, Wijburg FA, Baas F, Heijmans HS, Tabak HF, Wanders RJ, Distel B: Rhizomelic chondrodysplasia punctata is a peroxisomal protein targeting disease caused by a non-functional PTS2 receptor. Nat Genet 1997;15:377-380.

-34 Vohra N, Ghidini A, Alvarez M, Lockwood C: Walker-Warburg syndrome: prenatal ultrasound findings. Prenat Diagn 1993;13: 575-579.

- 35 Beinder EJ, Pfeiffer RA, Bornemann A, Wenkel H: Second-trimester diagnosis of fetal cataract in a fetus with Walker-Warburg syndrome. Fetal Diagn Ther 1997;12:197199.

-36 Evans MI, Quintero RA, King M, Qureshi F, Hoffman EP, Johnson MP: Endoscopically assisted, ultrasound-guided fetal muscle biopsy. Fetal Diagn Ther 1995;10:167-172.

37 Natacci F, Bedeschi MF, Righini A, Inverardi F, Rizzuti T, Boschetto C, Triulzi F, Spreafico R, Frassoni C, Lalatta F: Norman-Roberts syndrome: characterization of the phenotype in early fetal life. Prenat Diagn 2007;27: 568-572.

38 Stioui S, Privitera O, Brambati B, Zuliani G, Lalatta F, Simoni G: First-trimester prenatal diagnosis of Roberts syndrome. Prenat Diagn 1992;12:145-149.

39 Zimmer EZ, Bronshtein M, Ophir E, Meizner I, Auslender R, Groisman G, Meyer H: Sonographic diagnosis of fetal congenital cataracts. Prenat Diagn 1993;13:503-511.

40 Hamela-Olkowska A, Dangel J, Roszkowski T, Garwolinski J, Pawlowska B, Zaremba J: Prenatal ultrasound findings in trisomy 18 : report of 38 cases. Ultrasound Obstet Gynecol 2005;26:381.

-41 Roberts F, Wisdom S, Howatson AG, Imrie S: Clinicopathological study of bilateral developmental cataracts diagnosed in utero. Graefes Arch Clin Exp Ophthalmol 2006; 244:237-242.

42 Romain M, Awoust J, Dugauquier C, Van Maldergem L: Prenatal ultrasound detection of congenital cataract in trisomy 21. Prenat Diagn 1999;19:780-782. 
43 Reches A, Yaron Y, Burdon K, Crystal-Shalit O, Kidron D, Malcov M, Tepper R: Prenatal detection of congenital bilateral cataract leading to the diagnosis of Nance-Horan syndrome in the extended family. Prenat Diagn 2007;27:662-664.

-44 Burdon KP, McKay JD, Sale MM, RussellEggitt IM, Mackey DA, Wirth MG, Elder JE, Nicoll A: Mutations in a novel gene, NHS, cause the pleiotropic effects of Nance-Horan syndrome, including severe congenital cataract, dental anomalies, and mental retardation. Am J Hum Genet 2003;73:1120-1130.

45 Cuillier F, Cartault F, Lemaire P, Gruau M, Alessandri JL: Subependymal pseudocysts in the fetal brain revealing Zellweger syndrome. J Gynecol Obstet Biol Reprod 2004; 33:325-329.

-46 Moser AE, Singh I, Brown FR, Solish GI, Kelley RI, Benke PJ, Moser HW: The cerebrohepatorenal Zellweger syndrome: increased levels and impaired degradation of verylong-chain fatty acids and their use in prenatal diagnosis. New Engl J Med 1984;310: 1141-1146.

-47 Solish G, Moser H, Ringer LD, Moser A, Carol T, Schutt E: The prenatal diagnosis of the cerebro-hepato-renal syndrome of Zellweger. Prenat Diagn 1985;5:27-34.

-48 Endres W, Schaub J, Stefani FH, Wirtz A, Zahn V: Cataract in a fetus at risk for oculocerebro-renal syndrome. Klin Wochenschr 1977;55:141-144.

49 Tsuru T, Yamagata T, Momoi MY, Okabe I: Prenatal diagnosis of Lowe syndrome by OCRL1 messenger RNA analysis. Prenat Diagn 1999;19:269-270.

-50 Suchy SF, Lin T, Horwitz JA, O’Brien WE, Nussbaum RL: First report of prenatal biochemical diagnosis of Lowe syndrome. Prenat Diagn 1998;18:1117-1121.
1 Puder KS, Treadwell MC, Gonik B: Ultrasound characteristics of in utero infection. Infect Dis Obstet Gynecol 1997;5:262-270.

52 Mace M, Cointe D, Six C, Levy-Bruhl D, Parent du Chatelet I, Ingrand D, Grangeot-Keros L: Assessment of the diagnostic value of RT-PCR on amniotic fluid for prenatal diagnosis of congenital rubella infection. Pathol Biol 2004;52:540-543.

53 Nigro G, Mazzocco M, Anceschi M, La Torre R, Antonelli G, Cosmi E: Prenatal diagnosis of fetal cytomegalovirus infection after primary or recurrent maternal infection. Obstet Gynecol 1999;94:909-914.

54 Panda A, Sood NN, Agarwal LP: Corticosteroid induced glaucoma and cataract. Indian J Ophthalmol 1981;29:377-379.

55 Shahzad S, Suleman MI, Shahab H, Mazour I, Kaur A, Rudzinskiy P, Lippmann S: Cataract occurrence with antipsychotic drugs. Psychosomatics 2002;43:354-359.

56 Bony C, Zyka F, Tiran-Rajaofera I, Attali T, De Napoli S, Alessandri JL: Warfarin embryopathy. Arch Pediatr 2002;9:705-708.

57 Hetzel PG, Glanzmann R, Hasler PW, Ladewick A, Bührer C: Coumarin embryopathy in an extremely low birth weight infant associated with neonatal hepatitis and ocular malformations. Eur J Pediatr 2006;165:358360.

58 Goyal R, Thompson D, Timms C, Wilson LC, Russell-Eggitt I: Review of cases presenting with microcephaly and bilateral congenital cataract in a paediatric cataract clinic Eye 2008;22:273-281.

59 Hennekam RC, van de Meeberg AG, van Doorne JM, Dijkstra PF, Bijlsma JB: Martsolf syndrome in a brother and sister: clinical features and pattern of inheritance. Eur J Pediatr 1988;147:539-543.
60 Bora E, Cankaya T, Alpman A, Karaca E, Cogulu O, Tekgul H, Ozkinay F: A new case of Martsolf syndrome. Genet Couns 2007;18: 71-75.

61 Abdel-Salam GM, Hassan NA, Kayed HF, Aligianis IA: Phenotypic variability in Micro syndrome: report of new cases. Genet Couns 2007; 18:423-435.

62 Grizzard WS, O’Donnell JJ, Carey JC: The cerebro-oculo-facio-skeletal syndrome. Am J Ophthalmol 1980;89:293-298.

-63 Sakai T, Kikuchi F, Takashima S, Matsuda H, Watanabe N: Neuropathological findings in the cerebro-oculo-facio-skeletal (PenaShokeir II) syndrome. Brain Dev 1997;19: 58-62.

64 Weaver RG, Rao N, Thomas IT, Pettenati MJ: De novo inv(2)(p21q31) associated with isolated bilateral microphthalmia and cataracts. Am J Med Genet 1991;40:509-512.

65 Paladini D, D’Armiento M, Ardovino I, Martinelli P: Prenatal diagnosis of the cerebrooculo-facio-skeletal (COFS) syndrome. Ultrasound Obstet Gynecol 2000;16:91-93.

66 Salim A, Wiknjosastro GH, Danukusumo D, Barnas B, Zalud I: Fetal retinoblastoma. J Ultrasound Med 1999;17:717-720.

67 Maat-Kievit JA, Oepkes D, Hartwig NG, Vermeij-Keers C, van Kamp IL, van de Kamp JJP: A large retinoblastoma detected in a fetus at 21 weeks of gestation. Prenat Diagn 1993;13:377-384.

68 Wiesel TN, Hubel DH: Comparison of the effects of unilateral and bilateral eye closure on cortical unit responses in kittens. J Neurophysiol 1965;28:1029-1040.

69 Katorza E, Rosner M, Zalel Y, Gilboa Y, Achiron R: Prenatal ultrasonographic diagnosis of persistent hyperplastic primary vitreous. Ultrasound Obstet Gynecol 2008;32:226228 . 